\title{
SEMIOTIKA PUISI TIDAK ADA NEW YORK HARI INI KARYA M AAN MANSYUR
}

\author{
Ahsani Taqwiem \\ Fakultas Keguruan dan Ilmu Pendidikan, Program Studi Pendidikan Bahasa dan Sastra Indonesia \\ Universitas Lambung Mangkurat \\ ahsanitaqwiem@ulm.ac.id
}

\begin{abstract}
This study aimed to discover the meaning of Tidak Ada New York Hari Ini's poetry by M. Aan Mansyur. The approach used in this research is semiotic Michael riffaterre. This research was conducted with several stages, namely; understand the non-existence of expression; conducting heuristic and hermeneutic readings; search for its matrix, model, and variant; as well as finding the hypogram of the text. The results of the discussion can reveal the meaning that contained in the poetry. The discussion also shows poetry Tidak Ada New York Hari Ini is a response from the preceding hypogram.
\end{abstract}

Keywords: study of semiotics; poetry; Michael Riffaterre

\section{ABSTRAK}

Penelitian ini bertujuan untuk menemukan makna dari puisi Tidak Ada New York Hari Ini karya M. Aan Mansyur. Pendekatan yang digunakan adalah pendekatan semiotik Michael riffaterre. Penelitian ini dilakukan dengan beberapa tahap, yaitu; memahami ketidaklangsungan ekspresi; melakukan pembacaan heuristik dan hermeneutik; mencari matriks, model, dan variannya; serta menemukan hipogram dari karya sastra tersebut. Hasil pembahasan mampu mengungkap makna yang terkandung di dalam puisi. Pembahasan juga menunjukan bahwa puisi Tidak Ada New York Hari adalah respon dari hipogram yang mendahuluinya.

Kata kunci: kajian semiotika; puisi; Michael Riffaterre

\section{Pendahuluan}

Puisi adalah salah satu genre di dalam karya sastra yang isinya bukan suatu teks kosong. Salah satu hal yang mengisi puisi adalah makna yang dikandungnya. Sebagai karya sastra maka puisi harus memenuhi kriteria karya yang baik, menurut Horace (Horatius) karya sastra harus memiliki sifat dulce et utile atau nikmat dan bermanfaat. Salah satu upaya mengambil manfaat dari puisi adalah dengan jalan memahami makna dari puisi. Hal ini menjadikan puisi tidak hanya indah secara struktur tetapi juga mampu menjadi media penyampai pesan atau media pembelajaran yang ideal.

Menemukan makna puisi dapat dilakukan dengan mengidentifikasi simbolsimbol di dalamnya. Semiotika adalah ilmu tentang tanda-tanda, mempelajari fenomena sosial-budaya, termasuk sastra sebagai sistem tanda (Preminger, 1974: 980). Salah satu teori semiotik adalah yang dikemukakan oleh Michael Riffaterre. Teori Riffatere secara spesifik berusaha menemukan arti dan makna yang terkandung di dalam karya sastra khususnya yang bergenre puisi.

Puisi yang dipilih untuk diartikan dan dimaknai adalah puisi M Aan Mansyur. M Aan Mansyur termasuk penulis puisi kontemporer Indonesia. Kontemporer dapat diartikan baru dalam rentang waktu penulisanan atau dalam gaya penulisan. Sesuai dengan riwayat hidup yang tertulis di kumpulan puisinya dengan judul "Tidak Ada New York Hari Ini" disebutkan bahwa dia lahir di Bone, Sulawesi Selatan. Bekerja 
sebagai relawan di Komunitas Ininnawa dan pustakawan di Katakerja, Makassar. Selain puisi, ia juga menulis prosa dan esai. Bukubukunya yang sudah terbit antara lain Aku Hendak Pindah Rumah (2008), Cinta yang Marah (2009), Tokoh-tokoh yang Melawan Kita dalam Satu Cerita (2012), Kukila (2012), Kepalaku: Kantor Paling Sibuk di Dunia (2014), dan Melihat Api Bekerja (2015). Tahun 2016 M. Aan Mansyur ditunjuk sebagai penulis puisi yang menjadi puisi-puisi Rangga di dalam film Ada Apa Dengan Cinta 2. Hasil karyanya seolah mampu membawa stigma puisi itu usang dan klasik menjadi karya yang cair dan mampu hidup bersandingan dengan budaya populer lain. Oleh sebab itu, $M$ Aan Mansyur dalam daftar seniman muda penuh talenta bertajuk The Next Big Things in Indonesia Culture yang disusun harian Jakarta Globe tahun 2015.

\section{METODE}

Pendekatan penelitian ini adalah pendekatan semiotik. Hakikatnya pendekatan semiotik adalah lanjutan dari pendekatan strukturalisme. Semiotika Riffaterre digunakan untuk memaknai objek kajian yaitu puisi Tidak Ada New York Hari Ini karya M. Aan Mansyur. Riffaterre memandang bahwa untuk mendapatkan makna sajak secara utuh, pertama kali dapat dilakukan dengan pembacaan heuristik dan hermeneutik atau pembacaan rektroaktif. Pembacaan heuristik adalah pembacaan yang didasarkan pada konvensi kebahasaan (sistem semiotik tingkat pertama), sedangkan pembacaan hermeneutik adalah pembacaan yang didasarkan pada konvensi kesastraan (sistem semiotik tingkat kedua).

Bahasa puisi tidak seperti bahasa sehari-hari, namun lebih ke arah usaha menyatakan ekspresi secara tidak langsung atau indirection. Ketidaklangsungan ekspresi ini diakibatkan oleh pemaknaan puisi yang bersifat pengubahan makna atau displacing of meaning, penciptaan makna atau creating of meaning, dan perusakan makna atau distorting of meaning (Riffaterre, 1978:2).

Penggantian arti menurut Riffaterre disebabkan oleh penggunaan metafora dan metonimi dalam karya sastra. Metafora dan metonimi ini dalam arti luasnya untuk menyebut bahasa kiasan pada umumnya, tidak terbatas pada bahasa kiasan metafora dan metonimi saja. Selanjutnya penyimpangan arti menurut Riffaterre disebabkan oleh tiga hal, yaitu ambiguitas, kontradiksi, dan nonsense. Ambiguitas disebabkan oleh bahasa sastra itu berarti ganda (polyinterpretable), lebih-lebih bahasa puisi. Kontradiksi berarti mengandung pertentangan, disebabkan oleh paradoks atau ironi. Sedangkan penciptaan arti menurut Riffaterre merupakan konvensi kepuitisan berupa bentuk visual yang secara linguistik tidak mempunyai arti, tetapi menimbulkan makna dalam sajak (karya sastra) (Kaelan, 2009: 251).

\section{KETIDAKLANGSUNGAN MAKNA PUISI}

Ketidaklangsungan ekpresi menurut Riffatere disebabkan oleh tiga hal, penggantian makna atau displacing of meaning, penciptaan makna atau creating of meaning, dan perusakan makna atau distorting of meaning. Berikut disajikan puisi Tidak Ada New York Hari Ini karya M. Aan Mansyur dengan penambahan nomor pada tiap baris untuk memudahkan proses identifikasi, penyebutan dan analisis.

\section{Tidak Ada New York Hari Ini}

Tidak ada New York hari ini. (1)

Tidak ada New York kemarin. (2) 
Aku sendiri dan tidak berada di sini.

Semua orang adalah orang lain. (4)

Bahasa ibu adalah kamar tidurku. (5)

Kupeluk tubuh sendiri. (6)

Dan cinta-kau tak ingin aku (7)

mematikan mata lampu. (8)

Jendela terbuka (9)

dan masa lampau memasukiku sebagai angin. (10)

Meriang. Meriang. Aku meriang.

Kau yang panas di kening. Kau yang dingin di kenang. (12)

\section{Penggantian Makna}

Penggantian makna terjadi ketika sebuah tanda bergeser dari satu makna ke makna lain atau berfungsi mewakili makna lain. Hal ini terjadi di dalam sebuah teks karena penggunaan gaya bahasa di dalam karya sastra seperti metafora dan metonimi.

Metafora dan metonimi ini dalam arti luasnya untuk meyebut bahasa kiasan pada umumnya, tidak terbatas pada bahasa kiasan atau metafora saja. Hal ini disebabkan oleh metafora dan metonimi itu merupakan bahasa kiasan yang sangat penting hingga untuk mengganti bahasa kiasan lainnya, yaitu simile (perbandingan), personifikasi, senekdoki, perbandingan epos, dan alegori (Kaelean, 2009: 251).

Puisi Tidak Ada New York Hari Ini memiliki beberapa penggantian makna seperti yang dimaksud oleh Riffaterre. Di baris (10) masa lampau dipersonifikasikan sebagai seseorang yang memasuki sebuah ruangan seperti layaknya angin, udara yang mengalir dari tempat yang bertekanan tinggi ke tempat yang bertekanan lebih rendah. Masa lampau adalah benda abstrak yang tidak memiliki sifat-sifat insani selayaknya manusia. Masa lampau juga merupakan sebuah metafora akan seseorang. Seseorang yang disebut-sebut Aku di dalam puisi. Seseorang yang membuat Aku tidak sanggup menutup jendela saat kenangan akan seseorang yang disebutnya di dalam puisi datang. Jendela adalah metafora dari jiwa dan raga, pikiran dan perasaan. Ketika jendela dibiarkan terbuka, padahal mungkin mampu ditutup, maka Aku membuka dirinya dan membiarkan diri terbuka akan kenangan masa lalu. Aku pasrah dalam menerima segala hal tentang seseorang yang dimetaforakan sebagai angin (10).

\section{Penciptaan Makna}

Penciptaan arti menurut Riffaterre merupakan konvensi kepuitisan yang berupa bentuk visual yang secara linguistik tidak mempunyai arti, tetapi menimbulkan makna dalam sajak (karya sastra). Jadi, penciptaan arti ini merupakan organisasi teks, di luar linguistik. Di antara perantaranya adalah pembaitan, enjambement, persajakan (rima), tipografi, dan homologues (Kaelan, 2009: 252).

Puisi Tidak Ada New York Hari Ini pada bait pertama memiliki rima atau sajak akhir yang sama seperti terlihat pada huruf $\mathrm{i}$ pada baris (1) dan (3), sedangkan huruf $n$ ada pada baris (3) dan (4). Perulangan huruf yang teratur ini memberikan bunyi yang efoni. Efoni adalah kombinasi bunyi yang merdu, bunyi yang indah (Pradopo, 2014: 28).

Pengulangan huruf mampu menimbulkan perasaan, imajinasi dan pengalaman kepada pembaca. Huruf ng yang diulang sebanyak 7 kali di baris (11) 
dan (12) adalah bunyi sengau yang memberi nuansa lirih. Meriang, kening, kenang, serta yang adalah rangkaian kata yang menimbulkan efoni sendu dan rindu.

\section{Penyimpangan Makna}

Penyimpangan disebabkan oleh tiga hal, yaitu ambiguitas, kontradiksi, dan nonsense. Ambiguitas disebabkan oleh bahasa sastra itu berarti ganda (polyinterpretable), lebih-lebih bahasa puisi. Kontradiksi berarti mengandung pertentangan, disebabkan oleh paradoks atau ironi. Nonsense adalah kata-kata yang secara linguistik tidak mempunyai arti, sebab hanya berupa rangkaian bunyi yang tidak terdapat dalam kamus. Akan tetapi, dalam puisi nonsense itu mempunyai makna, yaitu arti sastra karena konvensi sastra, misalnya konvensi mantra (Kaelan, 2009: 251).

Tidak Ada New York Hari Ini memiliki beberapa kata yang menunjukan aspek ambiguitas seperti pada baris (5). Bahasa ibu memiliki pilihan makna, pertama ia adalah bahasa pertama yang diperoleh seorang manusia, sedangkan makna yang kedua bisa bermakna bahasa yang dimiliki oleh sosok ibu si Aku. Kedua makna ini memberikan pergeseran dan pilihan makna. Apakah Aku rindu pada daerah kelahirannya, tempat Dia memperoleh bahasa pertama, atau rindu kepada ibunya?

Penyimpangan makna lewat kontradiksi di dalam puisi Tidak Ada New York Hari Ini terlihat dari baris (1) dan (2) yang beroposisi dengan baris (3). Kota New York pada baris (1) dan (2) adalah salah satu kota paling padat penduduknya di dunia. Ironi saat memahami bahwa di kota dengan jumlah manusia yang begitu banyak ada seseorang yang ternyata merasa kesepian. Baris (3) secara tersirat menunjukan Aku merasakan sesuatu yang salah. Kontradiksi yang memberikan makna bahwa aku merasa ada 'sesuatu' yang begitu dalam hingga mampu menepikan keramaian yang nyata di sekitarnya.

\section{PEMBACAAN HEURISTIK}

Pembacaan heuristik atau pembacaan tahap pertama berkaitan dengan memberikan makna secara langsung, harfiah, tersurat dan aktual. Pembacaan heuristik akan menghasilkan pembacaan yang bersifat mimetik serta membangun arti yang heterogen (Faruk, 1996: 26). Berikut adalah hasil pembacaan berdasarkan struktur bahasa dari puisi Tidak Ada New York Hari Ini karya M Aan Mansyur.

Tidak ada pada baris (1) adalah ekpresi negatif yang menandakan pengingkaran terhadap keberadaan. Sebuah pilihan sikap dari pernyataan atas eksistensi ada atau tidak ada. Dua bait pertama puisi ini menggunakan tidak ada sebagai pembuka serta merujuk pada objek yang sama persis, sebuah kota bernama New York. Tidak ada New York, hari ini dan kemarin. Apakah akan ada nanti? Atau memang bagi Aku sebenarnya tidak pernah ada? Aku sendiri, tidak ada orang lain, hanya diri sendiri. Saat Aku menyebutkan Aku Sendiri, apa perasaan yang menunjukkan bahwa Aku tidak berada pada tempat yang seharusnya. Tidak di sini, namun di tempat lain. Semua orang, selain diri $A k u$ adalah orang lain, orang yang tidak dikenal.

Bahasa Ibu dari Aku adalah kamar tidurku. Tidak sama dengan bahasa ibu orang lain. Sebab ibu memiliki karakter yang tidak bisa disamakan dengan ibu yang lain. Baris (1) dan (2) Aku menyebut New York, dari pernyataan ini dapat dipahami bahwa Aku dan Ibu terpisah jarak. Karena itu, untuk menuntaskan rindu salah satu caranya terlihat saat Aku mengatakan Kupeluk tubuhku sendiri, karena tidak ada tubuh orang lain. Aku sendirian. Dan cinta, entah cinta perasaan atau cinta sebagai objek 
dari puisi Aku. Cinta yang tak ingin aku mematikan mata lampu, Cinta yang tidak ingin $A k u$ merasa terang daan tenang.

Jendela terbuka, jelas $A k u$ berada di dalam kamar yang memiliki jendela konvensional yang bisa dibuka tutup. Salah satu fungsi jendela adalah sebagai jalan keluar masuk udara. Angin yang dirasakan Aku selayaknya masa lampau. Angin yang menerpa dengan intensitas yang berlebih akan mengakibatkan gangguan kesehatan, masuk angin yang ditandai dengan meriang. Semuanya tentang seseorang yang $A k u$ panggil dengan sebutan Kau. Kau yang jadi penyebab rasa meriang dan panas di kening, kau yang dingin di kenang. Jelas bait ini memberikan gambaran bahwa Aku merasakan demam, baik secara fisik maupun mental. Merasa dingin padahal panas, atau sebaliknya.

\section{PEMBACAAN HERMENEUTIK}

Puisi Tidak Ada New York Hari Ini dibuka dengan kalimat yang persis dengan judul puisinya. Pengulangan tidak ada seperti mengatakan bahwa aku, tokoh di dalam puisi telah melewati proses mencari dan berakhir nihil. Tentu sesuatu yang dicari secara berulang memiliki kadar penting yang membedakannya dari hal-hal biasa. Sebab aku telah mencarinya hari ini dan kemarin. Mungkin $A k u$ tidak pernah merasakan New York di dalam dirinya.

Aku sendiri dan tidak berada di sini. Sebuah bait yang ingin menyampaikan kekosongan. Aku adalah penyebutan diri yang memiliki tendensi ego melebihi penggunaan kata saya. Aku adalah simbol tunggal. Sebuah keadaan yang tidak menyenangkan, ditambah penulis memasangkannya dengan kata sendiri. Aku yang sepi dan tidak berada di sini, tidak berada di New York. New York adalah kota paling padat penduduknya di Amerika Serikat, bahkan termasuk kota paling padat di dunia. Hal ini wajar sebab New York adalah metropolitan yang menjadi jantung ekonomi, media, budaya, seni, mode, riset dan hiburan dunia. Sebuah kota yang hampir tidak menyediakan ruang bagi orang yang merasa sendiri. Kontrakdiksi yang dihadirkan penulis sebagai sebuah simbol yang menunjukkan bagaimana rasa kesepian yang sangat dalam lebih-lebih kesepian itu dirasakan di kota paling riuh di dunia. $A k u$ hilang diri di kota yang selalu terjaga, The City That Never Sleeps.

Tidak Ada New York Hari Ini adalah puisi dari film AADC 2 yang merupakan lanjutan dari film AADC 1. Hal ini memberikan gambaran mengapa kota new York yang dijadikan simbol khususnya pada baris (1) dan (2). New York adalah kota tempat Rangga pergi dan meninggalkan Cinta untuk melanjutkan pendidikan. New York menjadi penanda jarak sebab Cinta berada di Jakarta.

Semua orang adalah orang lain. Penduduk kota tidak mampu membuat $A k u$ merasa kerasan. Aku merasa tidak hidup dan kosong. Semua orang menandai bahwa Aku telah mencoba beberapa orang, atau banyak orang untuk menjadi seseorang yang berarti bagi dirinya. Namun, usaha itu gagal karena $A k u$ sadar bahwa seberapa pun keras berusaha, Semua orang tetaplah orang lain.

Bait pertama puisi Tidak Ada New York Hari Ini secara keseluruhan menjadi gambaran perasaan Aku yang merasa serba salah, tidak penuh sebagai dirinya sendiri. Ada bagian $A k u$ yang hilang dan terus dicari, namun pada satu titik aku memahami bahwa hal atau seseorang yang dicarinya tidak akan Dia temukan di tempatnya sekarang. Satusatunya cara adalah $A k u$ harus pulang.

Kamar tidur adalah ruang personal. Tempat hal-hal intim dan individual tersimpan dan terjaga dari orang lain. Sebuah tempat yang menawarkan privasi 
level atas. Tempat kita selalu pulang dalam keadaan apapun. Tempat pulang itu dipasangkan dengan bahasa ibu. Sesuatu yang sangat dekat, sangat kita rindukan. Dua simbol itu memberikan kita pemahaman bahwa $A k u$ yang berada di tempat yang asing tersebut menjadikan tempat tidurnya sebagai satu-satunya tempat kembali dalam usahanya lari dari kekosongan.

Di dalam kamar tidur itulah $A k u$ memeluk dirinya sendiri. Sebuah ungkapan yang begitu dalam dan menyakitkan. Sebab peluk adakah kata kerja yang memerlukan orang kedua sebagai objek yang mendapat perlakuan tersebut. Apa rasanya memeluk diri sendiri? Apa karena memang sendiri atau ada orang lain namun tidak bisa dipeluk, atau bahkan pernah memeluk orang lain namun rasanya peluk yang didapat tidak sama. Memeluk diri sendiri adalah sebuah ungkapan perayaan atas perasaan kosong yang begitu menyakitkan.

Terdapat ambiguitas pada baris (7) dan (8). Cinta di dalam baris tersebut bisa berarti perasaan sayang atau cinta kalau kita melihatnya dari penggunaan huruf nonkapital yang mengawali kata tersebut, namun ketika ada garis yang menghubungkannya dengan kata kau- tentu kau berarti kata ganti yang merefer kepada seseorang bernama Cinta. Dualisme makna ini sekaligus menjadi kelebihan puisi ini sebab orang akan langsung mengingat bahwa Cinta adalah orang yang Aku cinta.

Cinta tidak membiarkan $A k u$ melupakannya, bahkan saat tidur. Cinta tidak membiarkan $A k u$ terlelap. Sebab mematikan mata lampu saja tidak mampu, apalagi mematikan kehidupan walau sebentar, dalam arti memejamkan mata. Begitu jelas bayang-bayang Cinta menghantui, cinta $A k u$ kepada Cinta. Tidak ada celah $A k u$ untuk menepikan cintanya kepada Cinta walau sekejap. Cinta menjadi semacam segalanya bagi $A k u$.

Jendela terbuka, kata jendela seperti sebuah pemikiran, tempat kita menengok segala sesuatunya. Seringkali jendela ditutup agar tidak ada benda atau hal-hal yang mengganggu bisa masuk. Siapa yang masuk dan menggangu? Tentu kenangan dan bayangan akan Cinta yang terungkap di baris sebelumnya. Pada baris (10) terlihat apa yang sebenarnya tidak diinginkan $A k u$ untuk masuk ke dalam pikirannya. Masa lampau yang begitu mengganggu, atau gangguan tersebut menandakan sebuah rindu. Seperti angin yang leluasa masuk ketika sebuah jendela dibuka.

Angin yang masuk dari jendela dalam jumlah besar tentu akan berakibat buruk pada kesehatan. Meriang adalah penyakit paling lumrah ketika terkena angin yang berlebih. Sakit, ketika kenangan yang begitu dihindari ternyata berbalik dan menyerang pemikiran. Meriang akan memberikan efek panas dingin. Panas ketika tubuh disentuh namun sebenarnya di dalam ada rasa dingin, beku karena kenangan. Sakit yang kotradiktif, panas di luar dingin di dalam, senang di luar sedih di dalam, bahagia di luar ternyata luka di dalam, baik di fisik ternyata luka di jiwa.

\section{MATRIKS, MODEL, DAN VARIAN-VARIAN.}

Untuk memperjelas (dan mendapatkan) makna sajak (karya sastra) lebih lanjut, maka tema dan masalahnya ditemukan dengan mencari matriks, model, dan varian-variannya lebih dulu. Matriks itu harus diabstraksikan dari sajak atau karya sastra yang dibahas. Matriks itu tidak dieksplisitkan dalam sajak atau karya sastra (Riffaterre dalam Pradopo, 2011: 227).

Hasil pembacaan secara hereustik dan hermeneutik menghasilkan sebuah 
matriks yaitu, "Seseorang yang merasa asing dan rindu terhadap masa lalu". Matrik diaktualisasikan ke dalam puisi lewat model. Model adalah sebuah tanda yang khas, di dalam puisi model dapat diidentifikasi lewat sifatnya yang khas dan puitis. Tidak Ada New York Hari Ini nampaknya memiliki dua buah model yang saling adu kuat dalam hal puitisasi. Baris (1) dan (12) menjadi pembuka dan penutup yang kuat. Kedua model ini sangat monumental dan menjadi tanda yang khas. Model pertama dari baris (1) berasal dari rasa kesepian, keterasingan, kehampaan, yang jika ditarik secara umum adalah perasaan yang secara normal pernah dirasakan semua manusia. Perasaan sendiri, sepi, dan sunyi. Model kedua dari baris (12) berasal dari wacana masa lalu yang menghantui setiap orang, sebab manusia sedikit banyaknya dibangun dari masa lalu.

Matriks dan model itu kembali ditransformasikan ke dalam varian-varian yang diterjemahkan ke dalam baris-baris puisi. Varian pertama adalah cerita tentang kesepian yang dapat diidentifikasi di dalam baris (1), (2), (3), dan (4). Varian kedua adalah cerita keriduan yang sangat dalam yang dapat dirasakan lewat simbol-simbol bahasa ibu, kamar tidur, jendela, dan angin yang terdapat pada baris (5), (6), (7), (8), (9), dan (10). Varian ketiga adalah rasa sakit karena masa lalu, varian ini dapat dirasakan lewat diksi meriang, panas di kenang, dan dingin di kenang yang terdapat pada baris (11) dan (12).

\section{HIPOGRAM}

Hipogram adalah latar sebuah karya sastra tercipta. Latar penciptaan ini mungkin berupa peristiwa sejarah, masyarakat, alam dan kehidupan. Menafsirkan latar atau respon adalah tugas dari pembaca (Teeuw, 1983: 65). Peneliti dalam hal ini adalah juga seorang pembaca yang berusaha menemukan latar belakang dari penciptaan puisi Tidak Ada New York Hari Ini.

Tidak Ada New York Hari Ini adalah sebuah karya yang ditujukan untuk menjadi jiwa dari film Ada Apa Dengan Cinta 2. Film kedua tersebut tentu tidak bisa melepaskan diri dari pengaruh film pertama, meskipun jarak antara dua film tersebut mencapai 14 tahun dari tahun 2002 hingga kemunculan sekuelnya pada tahun 2016.

Proses memahami dan merespon sebuah film yang dilakukan M Aan Mansyur terhadap film Ada Apa Dengan Cinta 1 mampu memberikan jiwa dan meneruskan mitos kisah cinta Rangga dan Cinta menjadi jiwa dari puisi yang ada pada film Ada Apa Dengan Cinta 2. New York, simbol yang ada pada puisi Tidak Ada New York Hari, kota yang menjadi tujuan Rangga pada akhir film Ada Apa Dengan Cinta 1 mampu memberikan nafas dan rasa dingin sama seperti rasa dingin yang mengakhiri film Ada Apa Dengan Cinta 1. Tidak Ada New York Hari berhasil menjadi penghubung dua buah kisah yang terendap belasan tahun dan menghidupkannya kembali dengan baik.

\section{KESIMPULAN}

Semiotik adalah ilmu yang mempelajari tentang tanda. Salah satu teori semiotik adalah yang dikemukakan oleh Michael Riffaterre dengan menawarkan empat tahapan pendekatan untuk menemukan makna. Tahapan itulah yang digunakan dalam penelitian ini. Tahap pertama adalah menemukan ketidaklangsungan ekpresi yang disebabkan oleh tiga hal yaitu, penggantian makna atau displacing of meaning, penciptaan makna atau creating of meaning, dan perusakan makna atau distorting of meaning. Tahap kedua adalah melakukan pembacaan secara heuristik dan hermeneutik. Tahap ketiga adalah mengidentifikasi matriks, model, dan varian-variannya. Kemudian langkah 
terakhir adalah menemukan hipogram yang membuktikan bahwa puisi Tidak Ada New York Hari Ini hadir sebagai sebuah respon dari karya film yang menjadi latar belakangnya. Memaknai teks sastra dengan teori dan metode semiotika merupakan salah satu dari banyak pilihan teori pemaknaan yang berusaha menempatkan teks secara objektif.

\section{DAFTAR RUJUKAN}

Faruk. 1996. "Aku” dalam Semiotik Riffaterre, Semiotik Riffaterre dalam "Aku". Humaniora III. Yogyakarta: Buletin Fakultas Sastra Universitas Gadjah Mada.

Kaelan. 2009. Filsafat Bahasa Semiotika dan Hermeneutika. Yogyakarta: Paradigma.

Mansyur, M Aan. 2016. Tidak Ada New York Hari Ini. Jakarta: Gramedia Pustaka Utama.
Pradopo, Rahmat Djoko. 2011. PrinsipPrinsip Kritik Sastra. Yogyakarta: Gadjah Mada University Press.

Pradopo, Rachmat Djoko. 2014. Pengkajian Puisi. Yogyakarta: Gadjah Mada University Press.

Preminger, Alex (ed) dkk. 1974. Princenton Ecyclopedia of Poetry and Poetics. New Jersey: Princenton University Press.

Riffaterre, Michael. 1978. Semiotics of Poetry. Bloomington: Indiana University Press.

Teeuw, A. 1983. Membaca dan Menilai Sastra. Jakarta: Gramedia. 